\title{
THE RELATIONSHIP BETWEEN HAND LENGTH AND HEIGHT IN ADULT MALES OF NORTH INDIAN PUNJABI POPULATION.
}

Maheshwar Chawla, Rajkumar, Ramkumar Ashoka, Sushma Tomar, Lavlesh Kumar Mittal

1. Assistant Professor. Department of Anatomy, Gold Field Institute of Medical Sciences \& Research, Chhainsa, Ballabgarh, Faridabad, Haryana.

2. Demonstrator. Department of Anatomy, Gold Field Institute of Medical Sciences \& Research, Chhainsa, Ballabgarh, Faridabad, Haryana.

3. Professor \& HOD. Department of Anatomy, Gold Field Institute of Medical Sciences \& Research, Chhainsa, Ballabgarh, Faridabad, Haryana.

4. Assistant Professor. Department of Anatomy, Gold Field Institute of Medical Sciences \& Research, Chhainsa, Ballabgarh, Faridabad, Haryana.

5. Demonstrator. Department of Anatomy, Gold Field Institute of Medical Sciences \& Research, Chhainsa, Ballabgarh, Faridabad, Haryana.

\section{CORRESPONDING AUTHOR}

Dr. Maheshwar Chawla, c/o Raj nursing home,Sec-3, Near Aggarwal Public School, Ballabgarh, Faridabad (Haryana), E-mail: dr.rajkumarghanghas@yahoo.com,rghanghas@gmail.com Ph: 00919466833363,00919410066592

ABSTRACT: INTRODUCTION: Stature of an individual is an inherent characteristic, the estimate of which is considered to be an important assessment in identification of unknown human remains ${ }^{12}$.The stature prediction occupies relatively a central position both in anthropological research and in the identification necessitated by the medical jurisprudence or by medico legal experts. Estimation of stature of an individual from the skeletal material or from the mutilated or amputated limbs or parts of limbs has obvious significance in the personal identification in the events of the murders, accidents or natural disasters mainly concerns with forensic identification analysis ${ }^{8}$. Whether this is true for the North Indian Punjabi male population is not known till date. AIMS: The present study was done with an aim to establish relationship between height and hand length in adult males of north Indian Punjabi population, as it is not seen in the accessible literature till date to the best of our knowledge. MATERIALS AND METHOD: Height of 150 healthy male students between 18 to 25 years of age was measured with the help of an anthropometric rod. The height of all the students was measured in anatomical position keeping all the subjects erect. The height measured was vertical distance from the vertex to floor. Hand length is the direct linear distance between the distal wrist crease and the distal ends of most anterior projecting point i.e., tip of the middle finger. It is also the distance between midpoint of line joining the two stylion and Dactylion of middle finger. Result: - A positive correlation between height and hand length was observed and it was statistically significant. Regression equation for height estimation was formulated using hand length. For statistical analysis IBM (Statistical Package for Social Sciences) SPSS + Version 20 was used.

The mean difference of the height was $\mathbf{1 7 7 3 . 2 7 3} \pm \mathbf{7 8 . 8 3 2} \mathbf{~ m m}$ and Hand length (Right and Left) were $196.373 \pm 11.515$ and $196.267 \pm 11.546 \mathrm{~mm}$ respectively. CONCLUSION: The height and hand length measurements were statistically significant $(\mathbf{p}<\mathbf{0 . 0 0 0 1})$. Hand length is a good predictor of height. The correlation between hand length and height $(r=0.654$; $\mathbf{p}<\mathbf{0 . 0 0 0 1}$ ) was high and significant in all the subjects. The findings could also be of practical 
significance in the field of forensic medicine in case of identification of persons having amputated lower limbs due to accident, or mass disaster.

KEY WORDS: Height, hand length right and left side, anthropology, dactylion, stylion, Vertex, Anthropometeric rod, sliding calipers, Punjabi population.

INTRODUCTION: - Estimation of stature from incomplete skeletal and decomposing human remains is particularly important in personal identification. The relationship between specific body dimensions / proportions can be used to help solve crimes in the absence of complete evidence. For example, it has been proved that stature can be estimated from imprints of the hand, foot or footprints or from a shoe left at the scene of a crime. Similarly, the stature of a victim can be estimated when a part of body, such as a long bone, or hand, is all that remains ${ }^{10}$.

The earthquake in Turkey in August 1999 and the terrorist attack on the World Trade Centre created great challenges to identification efforts. The same is true for all mass disaster (wars, accidents, terror events and natural disasters), where proper stature estimation is important for identification of the victims ${ }^{11}$.

Anthropometric measurements are part of the nutritional assessment which is an important component of health care. Measuring the individual stature with accuracy is very important because it is the basis of estimating basal energy expenditure and consequent nutrient needs and to calculate indices of nutrition. However, common methods of nutritional anthropometric assessment are not entirely satisfactory in elderly person. Certain measurements such as stature may be difficult to obtain because of postural changes, thinning of disks of spinal column and diminution in the height of the vertebrae and are associated with ageing ${ }^{17}$.

Relationship between the dimensions of individual body segments and the whole body has been of interest to artists, anthropologists and scientists for many years. Height

measurement is required for assessment of children's growth, calculation of nutritional indexes of children and adults for prediction and standardization of physiological parameters such as lung volumes, muscle strength, glomerular filtration, metabolic rate and for adjustment of drug dosage in patients. However, in many cases measurement of body height is difficult or impossible due to deformities of the trunk or legs, lower limb amputation, fractures or contractures or in patients who are unable to stand. ${ }^{20}$

Patients own hand as a tool to estimate the area of burn injury is well documented. The area of palmer surface of one hand has been estimated to be one percent of body surface area. This study also sought to determine natural history of the growth of the hand to permit development of a readily available bedside means of estimating hand area and body surface area $^{2}$.

To study the usefulness of hand size as guide in predicting body size, length of hand as a predictor of body mass and body surface was examined and it was found that hand length is a simple measurement that may be used as treatment guide. Hand length can predict body weight and body surface area independently of the gender of the subject ${ }^{3}$.

Health care providers often under value the clinical importance of accurate measurement of height. Yet height is a critical variable in the calculation of body surface area (BSA) for drug dosages, vital capacity, basal metabolic rate (BMR), renal clearance and body mass index (BMI). All of these are crucial factors in providing high quality health care to all patients and especially those with serious illnesses. Moreover, height can be difficult or impossible to measure accurately on patients who have conditions such as pain, weakness, compression fracture of vertebrae or paralysis 5 . 
MATERIAL AND METHODS: The present study was conducted to establish the relationship of Hand length measurement with Height in 150 male students of age group 18-25 years of Patiala who were born and brought up in Punjab.

APPARATUS: Height and Hand length right and left side were measured with anthropometer rod and sliding calipers.

Anthropometer Rod (Photograph No.1):- It consists of four segments which when joined together form a rigid rod of $200 \mathrm{~cm}$. There is a fixed sleeve on the top of the rod. An adjustable graduated cross bar passes through it. There is also a movable sleeve with an adjustable graduated cross bar, which registers the height measurements.

Sliding Calipers (Photograph No. 2): It consists of a $25 \mathrm{~cm}$ long straight bar. It has $12.5 \mathrm{~cm}$ long arm fixed at one end and there is a sliding sleeve with $12.5 \mathrm{~cm}$ long arm parallel to the first one. The arms are projected to an equal distance on both sides of the scale. They end in sharp points on one side and have blunted ends on the opposite. The sharp ends are used for taking measurements on the skeletons whereas the blunt ends are used for measuring the living.

PROCEDURE: Procedure was adopted from Singh and Bhasin ${ }^{15}$ (1968).

Measurement of Height (Photograph No. 4) :-Height is the vertical distance from the vertex to the floor.

During these measurements subject was asked to stand erect barefoot on a level floor against the wall with his back and hip touching the wall. The feet were parallel to each other and heel was touching the wall. The anthropometer rod was kept in the median sagittal plane of the subject and the reading was taken at the upper border of movable socket when the point of the cross bar was touching the vertex.

Measurement of Hand length (Photograph No. 5) :- It is the straight distance between the midpoint of line joining the two stylion and Dactylion of middle finger.

Bony land marks were marked with a marker and then measurement were taken.

Vertex (Photograph No. 2): It is the highest point on head when the head is in eye ear plane.

Dactylion (Photograph No. 3): It is the lowest point on anterior margin of middle finger with arm hanging on the side of the subject. Anterior margin is the tip of the finger (distal margin of the finger).

Stylion (Photograph No. 3): : It is the deepest point on the styloid process of radius while the arm is hanging by the side of the subject (stylion radiale). Stylion ulnare is the most distal point on the styloid process of ulna. It is located on the little finger side of the wrist.

Statistical Analysis: The obtained data were analysed statistically with the help of IBM SPSS VERSION .20

RESULTS: In present study, upper limb somatometeric data and height of 150 male students of Patiala was collected. 
$\mathrm{P}<0.0001$ - considered as statistically significant;

The height and Hand length (Right and Left) measurements were1773.273 \pm 78.832 $\mathrm{mm}$ and $196.373 \pm 11.515$ and $196.267 \pm 11.546 \mathrm{~mm}$ respectively.

\section{Regression Equation For Height (Table No. 3)}

$$
\begin{aligned}
\text { Height } & =27.058+0.095(\mathrm{HLR}) \\
& 26.489+0.096(\mathrm{HLL}) \\
& 27.058-\text { constant }(\mathrm{HLR}) \\
& \text { 26.489-constant (HLL) } \\
& \text { 0.095- coefficient (HLR) } \\
& \text { 0.096-coefficient (HLL) } \\
& \text { HLR-Hand Length Right } \\
& \text { HLL- Hand Length Left }
\end{aligned}
$$

DISCUSSION: The present study included 150 male students of Patiala aged 18-25 of Punjabi origin. Estimation of an individual's stature is an important parameter in forensic examinations and anthropological studies. Morphometry of the hand provides important evidence in a crime scene investigation which helps in the estimation of stature of a criminal ${ }^{7}$. This would be of special importance in certain circumstances, when there is difficulty in obtaining stature of non ambulatory persons or in case of chance complete hand prints of criminals or from amputated arm or hand. This will also be used for anthropologist, equipments designers, ergonomists and dress designers etc.

\section{- Height VS. HAND LENGTH (LEFT SIDE):}

\section{Correlation :-}

- The present study found that hand length of left side is correlated to height by a coefficient value of $0.654, \mathrm{P}<0.0001$ (table No. 2). Krishan and sharma in 2007 obtained a coefficient of correlation 0.609 in Rajput males of Himachal Pradesh ${ }^{9}$. Abdel-Malek in 1990 obtained coefficient of correlation 0.64 on left side for adult males of upper Egypt ${ }^{1}$. So the present data can be used for a comparative study of the same parameter in adult Punjabi males. All the above studies show that hand length of left sided is correlated to height.

Regression Equation: Regression equation has been derived from which height can be estimated with hand length of left side as (variable) in male of Punjabi origin. The equation is as follows:

$$
H(\mathrm{~mm})=26.489+0.096 \text { (HL of Left Side in mm) (Table No.3) }
$$

Using this equation, stature can be estimated in adult Punjabi males. This is important in cases of mass disasters where disintegrated and amputated body parts are found very commonly and identification is integral part of investigation. 
Regression equation for adult Punjabi males was derived by Bhatnagar et $\mathrm{al}^{4}$ in 1984 which is as follows:

$$
\mathrm{H}(\mathrm{cm})=127.97+2.06(\text { Hand length in } \mathrm{cm})
$$

Dr. Sunil et al in 2005 derived regression equation in healthy individual ( Male And Female) studying in various colleges of Delhi' ${ }^{6}$. Which is as follows:

$$
\mathrm{H}(\mathrm{cm})=85.84+4.32(\text { Hand length in } \mathrm{cm})
$$

Regression equation for adult Punjabi males was derived by Thakur SD et al18 in 1978 which is as follows:

$\mathrm{H}=158.91+0.440$ (Hand length)

But no such equation was available for Punjabi males. So the present work will be helpful in calculation of stature from hand length of left side.

MEAN: Mean hand length in present study is $196.267 \mathrm{~mm}$ (Table No.1) for left hand. No such data was found for adult Punjabi males. While Krishan and Shrama in 2007 obtained the mean length as $18.21 \mathrm{~cm}$ in Rajput Females of Himachal Pradesh'.

\section{HEIGHT VS. HAND LENGTH (RIGHT SIDE)}

CORRELATION: In the present work, it has been found that hand length of right side is correlated to height by a coefficient value of $0.654, \mathrm{P}<0.0001$ (table No. 2). Krishan and sharama in 2007 obtained a coefficient of correlation 0.599 for Rajput males of Himchal Pradesh ${ }^{9}$. AbdelMalek et al. in 1990 deduced a coefficient of correlation 0.66 on right side for adult males of upper Egypt ${ }^{1}$. Isurani Ilayperuma and Ganananda Nanayakkara in 2009 obtained a coefficient of correlation 0.58 on right side in srilankans ${ }^{7}$. All the above studies show that hand length of right sided is correlated to stature.

So the present data can be used for a comparative study of the same parameter in adult Punjabi males.

REGRESSION EQUATION: Regression equation has been derived from which height can be estimated with hand length of right side as (variable) in males of Punjabi origin, which is as follows:

$$
\mathrm{H}(\mathrm{mm})=27.058+0.095 \text { (HL of Right Side in mm) (Table No. 3) }
$$

Thus, stature can be estimated in adult Punjabi males with the help of this equation, which is very important in identification of cases of mass disasters where disintegrated and amputated body parts are found very commonly.

Regression equation for adult Punjabi males was derived by Bhatnagar et $\mathrm{al}^{4}$ in 1984 which is as follows:

$\mathrm{H}(\mathrm{cm})=127.97+2.06($ Hand length in $\mathrm{cm})$ 
Dr. Sunil et al in 2005 derived regression equation in healthy individual ( Male And Female) studying in various colleges of Delhi' ${ }^{6}$. Which is as follows:

$\mathrm{H}(\mathrm{cm})=86.93+4.25$ (Hand length in $\mathrm{cm})$ in Male.

Regression equation for adult Punjabi males was derived by Thakur SD et al ${ }^{18}$ in 1987 which is as follows:

$H=51.388+5.988$ (Hand length)

But no such equation was available for adult Punjabi males. So the present work will be helpful in calculation of stature from hand length of right side.

MEAN: Mean hand length in present study is $196.373 \mathrm{~mm}$ (Table No. 1) for right hand. This finding is also supported by white et $\mathrm{al}^{19}$ in 1994 . According to them right hand of right handers is significantly larger than the left hand while Plato et al quoted that right hand is larger than the left regardless whether the person is right handed or left handed ${ }^{13}$. So considering the views of above mentioned authors, a correlation between hand length and handedness can be studied in future.

CONCLUSIONS: Correlating and predicting the equations for height from upper limb somatometric measurements, using data from 150 male students of Patiala (aged 18-25 years) of Patiala of Punjabi Origin, was the aim successfully achieved in this study.

The hand length and Height was correlated and obtained the coefficient of correlation 0.654 for left side and right side both. Regression equation has been derived for calculation of stature from hand length for both sides separately. Equations are as follows:

$\mathrm{H}=27.058+0.095$ (HL of Left Side)

$$
\mathrm{H}=26.489+0.096 \text { (HL of Right Side) }
$$

Mean of Height is 1773.273 .The mean of hand length is also obtained. It is 196.267 for left side and 196.373for right side. Mean hand length of right side is more comparatively to left side.

We have used MS Excel 2007 for our calculations and have considered a linear relationship between $X \& Y$ and as such have calculated a linear regression equation of the form $Y=A+B X$.

The linear regression equations derived from Hand length for estimation of height showed statistically significant relationship $(\mathrm{p}<0.0001)$ in Punjabi males.

\section{REFERENCES:}

1. Abdel-Malek AK, Ahmed AM, CL-Sharkaur SA, el-Hamid NA. Prediction of stature from hand measurements. Forensic Sci Int. 1990; Jul; 46(3):181-7.

2. Amirsheybani HR, Crecelius GM, Timothy NH, Pfeiffer M, Saggers GC, Manders EK. The natural history of growth of the hand: I hand area as a percentage of body surface area. Plast Reconstr surg 2001; 107 (3):726-33.

3. Amirsheybani HR, Crecelius GM, Timothy NH, Pfeiffer M, Saggers GC, Manders EK. Natural history of growth of the hand: part II--hand length as a treatment guide in the paediatric trauma patient. LTrauma. 2000;Sep; 49(3):457-60.

4. Bhatnagar DP, Thapar SP, Batish MK. Identification of personal height from the somatometry of the hand in Punjabi males. Forensic Sci Int. 1984 Feb; 24(2):137-41. 
5. Brown JK, Feng JY, Knapp TR. Is self-reported height or arm span a more accurate alternative measure of height. Clin Nurs Res. 2002 Nov; 11(4):417-32.

6. Dr. Sunil,Estimation of stature from hand length. JIAFM, $2005: 27$ (4). ISSN 0971- 0973 : 219-221.

7. Isurani Ilayperuma. Prediction of personal stature based on the hand length. Galle Medical Journal, Vol 14: No. 1, September 2009 : 14-18

8. Jasuja OP and Singh G. Estimation of stature from hand and phalanges. JIAFM 2004;26(3):0971-3.

9. Krishan $\mathrm{K}$ and Sharma A. Estimation of stature from dimensions of hands and feet in a North Indian population. Journal of Forensics and Legal Medicine 2007 Aug; 14(6):32732.

10. Ozaslan A, Iscan MY, Ozaslan I, Tugeu H, Koc S. Estimation of stature from body parts, Forensic science international 2003 Mar 12;132(1);40-5.

11. Ozaslan A, Koc S, Ozaslan I et al. Estimation of stature from upper extremity. Military medicine 2006;171(4):288-91.

12. Parikh CK. Identification in mass disasters. In: Parikh's text book of medical jurisprudence and toxicology. $2^{\text {nd }}$ edn. Delihi : CBS Publisher and Distributors; 1998. 6582.

13. Plato CC, wood JL and Norris AH. Bilateral asymmetry in bone measurement of the hand and lateral hand dominance. American Journal of Physical Anthropology 1980;52(1):2731

14. Reeves SL, Varakamin C, Henry CJ. The relationship between arm-span measurement and height with special reference to gender and ethnicity. Eur J Cunn Nutr 1996;50(6)398400.

15. Singh IP, Bhasin MK. Instruments In: A laborartory manual on biological anthropology: Anthropometry. $1^{\text {st }}$ ed. Delhi: Kamla-Raj Enterprises; 1968 15-74.

16. Steel MF, Mattox JW. Correlation of arm-span and knee height as proxy indicacators for height.JNDP 2001; 15: 1-5.

17. Tanchoco CC, Duante CA, Lopez ES. Arm span and knee height as proxy indicators for height. JNDP 2001; 15: 1-5.

18. Thakur SD, Rai KS. Determination of stature from hand measurements. Med. Sci. Law. $1978 ; 9(2): 25-28$.

19. White LE, Lucas G, Richard A et al. Cerebral asymmetry and handedness. Nature 1994; 368:197-8.

20. Zverev YP. Relationship between arm span and stature in Malawian adults. Ann Hum Biol 2003; 30(6):739-43.

Table No. 1SOMATOMETERIC DATA OF HEIGHT AND HAND LENGTH

\begin{tabular}{|c|c|c|c|c|c|c|}
\hline \multirow{2}{*}{$\begin{array}{l}\text { Study group } \\
(18-25 \text { years) }\end{array}$} & \multirow{2}{*}{$\begin{array}{l}\text { Sample } \\
\text { size (n) }\end{array}$} & \multicolumn{2}{|c|}{ HEIGHT (mm) } & \multicolumn{3}{|c|}{ HAND LENGTH } \\
\hline & & Mean \pm SD & Range & $\begin{array}{l}\text { Mean } \pm \text { SD } \\
\text { (Right } \\
\text { side) }\end{array}$ & $\begin{array}{l}\text { Mean } \pm \text { SD } \\
\text { (Left side) }\end{array}$ & Range \\
\hline $\begin{array}{c}\text { Male students of } \\
\text { Patiala of } \\
\text { Punjabi origin. }\end{array}$ & 150 & $\begin{array}{l}1773.273 \\
\pm 78.832\end{array}$ & $1640-1950$ & $\begin{array}{c}196.373 \pm \\
11.515\end{array}$ & $\begin{array}{c}196.267 \pm \\
11.546\end{array}$ & $170-236$ \\
\hline
\end{tabular}


Significant $(\mathrm{p}<0.0001)$.

Comparison of COEFFICIENT OF CORRELATION (Table No.2)

\begin{tabular}{|c|c|c|c|}
\hline $\begin{array}{c}\text { Serial } \\
\text { no. }\end{array}$ & Name of Authors & $\begin{array}{c}\text { COEFFICIENT OF } \\
\text { CORRELATION (L) }\end{array}$ & $\begin{array}{c}\text { COEFFICIENT OF } \\
\text { CORRELATION (R) }\end{array}$ \\
\hline 1. & Present study & 0.654 & 0.654 \\
\hline 2. & Krishana et al (2007) & 0.609 & 0.599 \\
\hline 3. & Abdel-Malek et al(1990) & 0.64 & 0.66 \\
\hline 4. & $\begin{array}{c}\text { Isurani Ilayperuma et } \\
\text { al(2009) }\end{array}$ & N.A & 0.58 \\
\hline
\end{tabular}

Comparison of Regression equation ( Table no.3)

\begin{tabular}{|c|c|c|c|c|c|}
\hline $\begin{array}{c}\text { Serial } \\
\text { no. }\end{array}$ & $\begin{array}{c}\text { Name of the } \\
\text { Authors }\end{array}$ & Sample size & Age & $\begin{array}{c}\text { Regression } \\
\text { equation (R) } \\
\text { (HL of right side) }\end{array}$ & $\begin{array}{c}\text { Regression } \\
\text { equation (L) } \\
\text { (HL of left .side) }\end{array}$ \\
\hline 1 & Present study & 150 ( Male) & $18-25$ yrs & $\mathbf{2 7 . 0 5 8 + 0 . 0 9 5}$ & $26.489+0.096$ \\
\hline 2. & $\begin{array}{c}\text { Bhatnagar } \\
(1984) \text { et al }\end{array}$ & 100 (Male) & $19-25$ yrs & $\begin{array}{c}127.97+2.06 \\
\text { (Hand length in } \\
\text { mm) }\end{array}$ & $\begin{array}{c}127.97+2.06 \text { (HL } \\
\text { of Left side in mm) }\end{array}$ \\
\hline 3. & $\begin{array}{c}\text { Isurani } \\
\text { Ilayperuma et } \\
\text { al(2009) }\end{array}$ & 140 (Male) & $20-23$ yrs & $103.732+3.493$ & N.A \\
\hline 4. & $\begin{array}{c}\text { Dr. Sunil et } \\
\text { al(2005) }\end{array}$ & 75 (Male) & $18-22$ yrs & $86.93+4.25$ & $85.84+4.32$ \\
\hline 5. & $\begin{array}{c}\text { Thakur SD et al } \\
(1987)\end{array}$ & 250 (male) & $17-25$ yrs & $51.388+5.988$ & $158.91+0.440$ \\
\hline
\end{tabular}

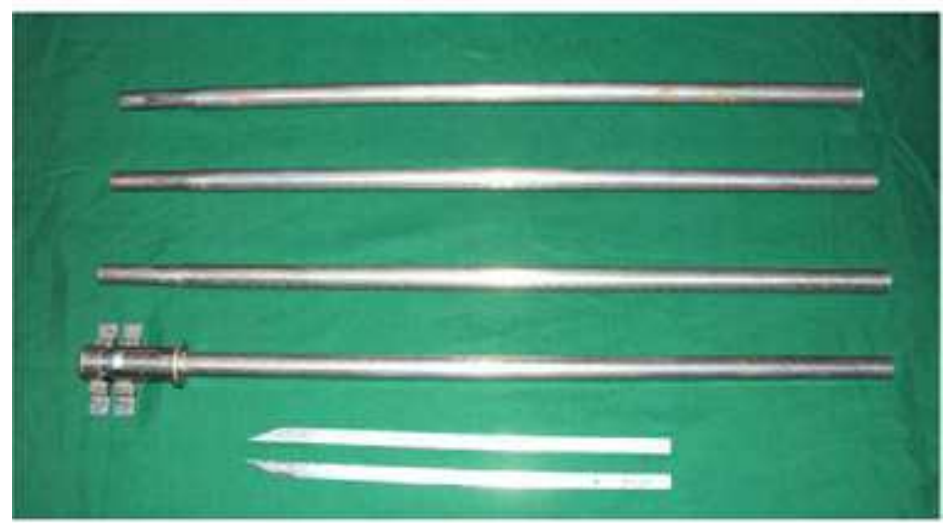

Photograph No. 1 (Anthropometer Rod) 


\section{ORIGINAL ARTICLE}

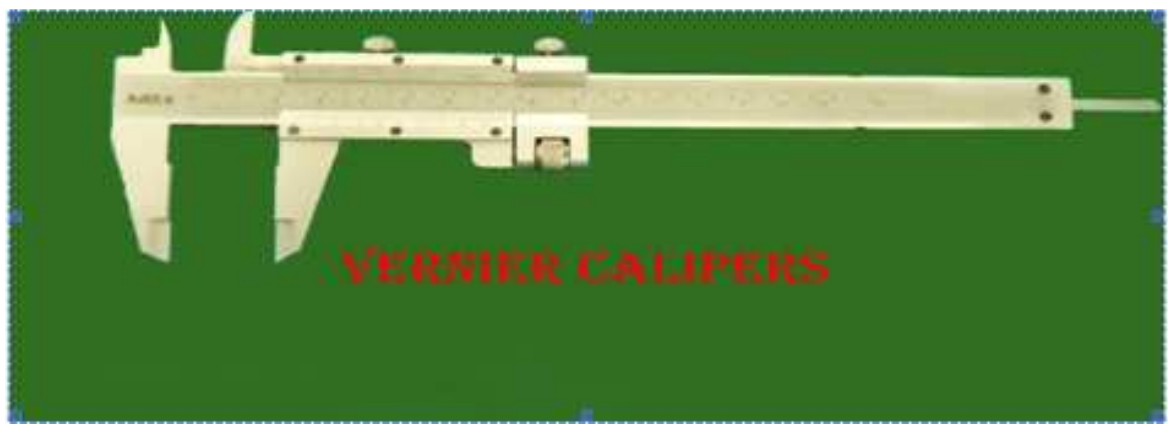

Photograph No. 2 (Sliding Calipers)

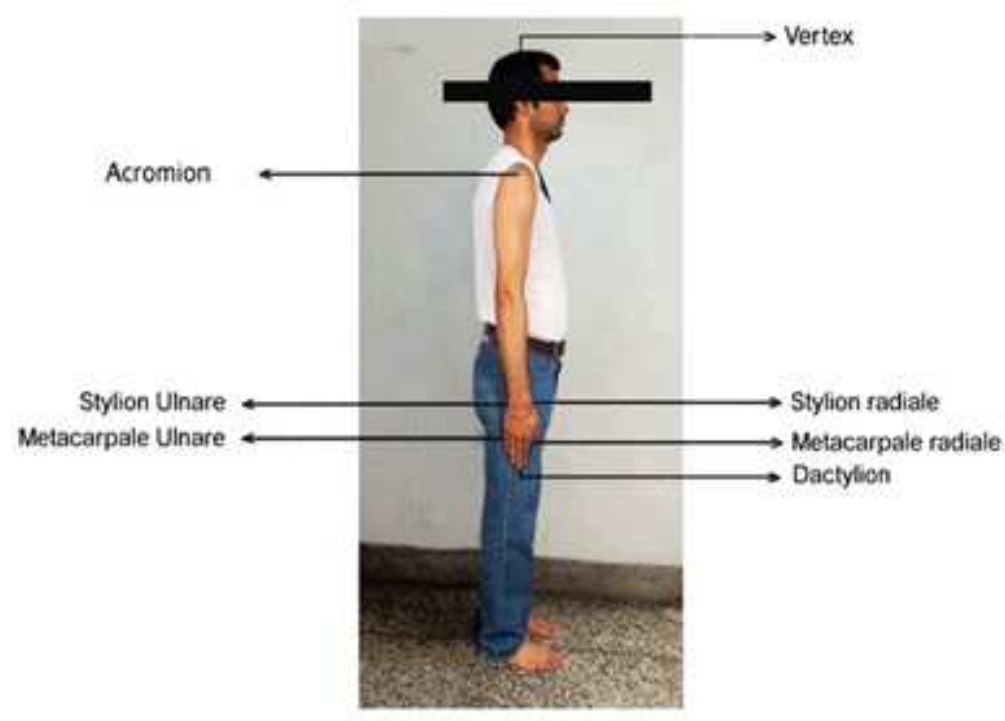

Photograph No. 3

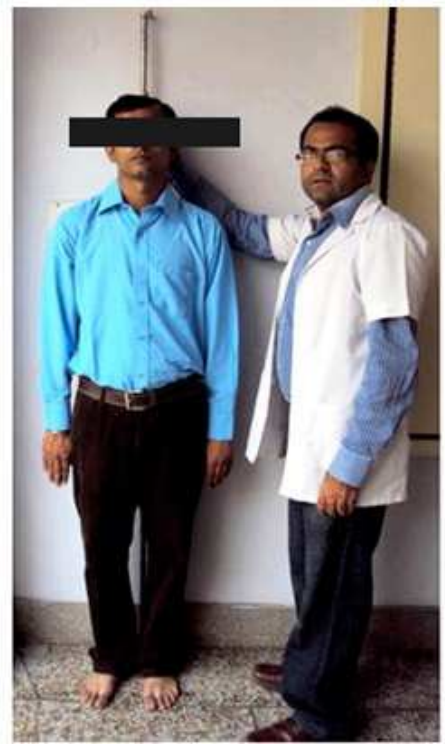

Photograph No. 4 


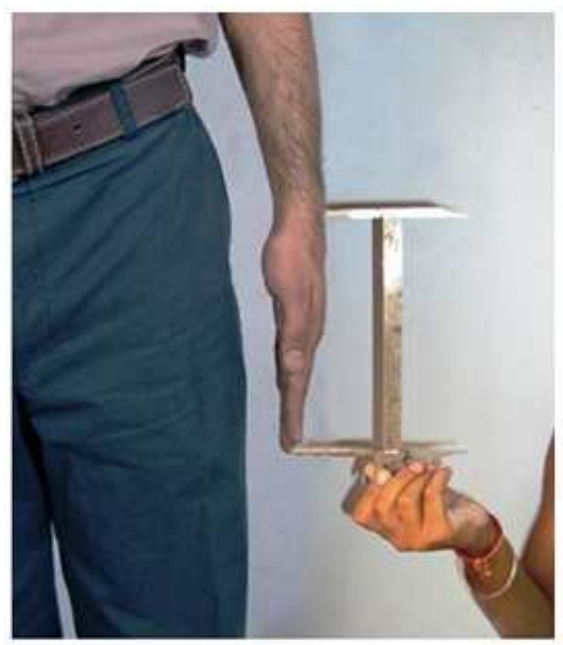

Photograph No. 5

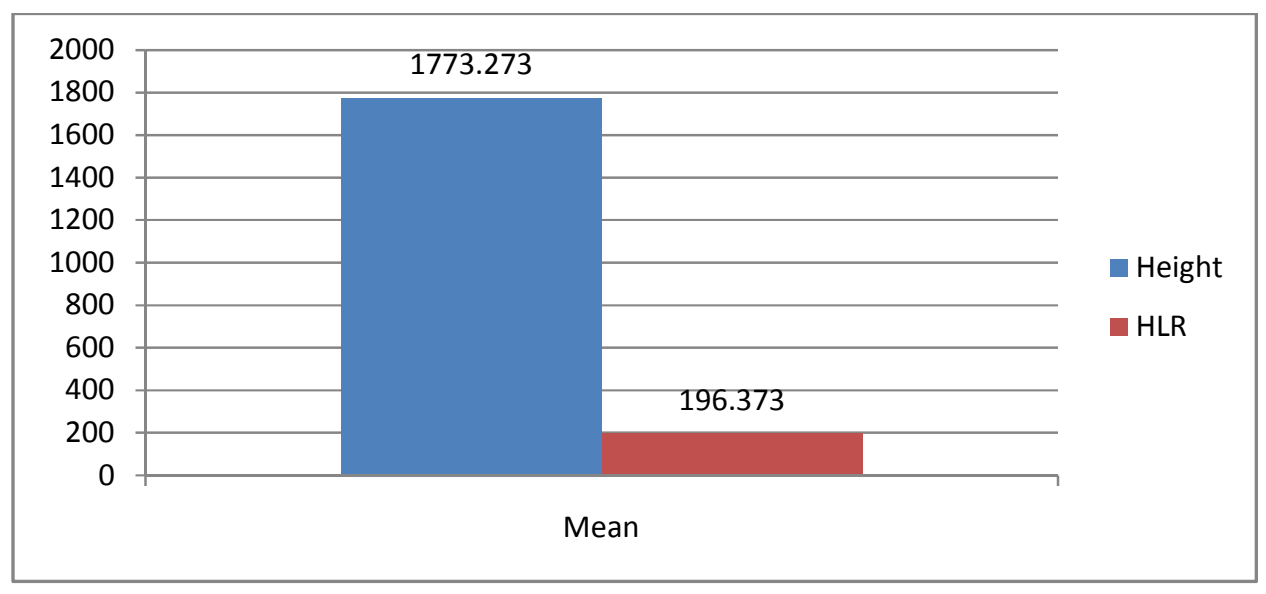

Mean of Height - Hand Length Right (HLR) Side Of Adult Males Of Punjabi Origin (Photograph No. 6)

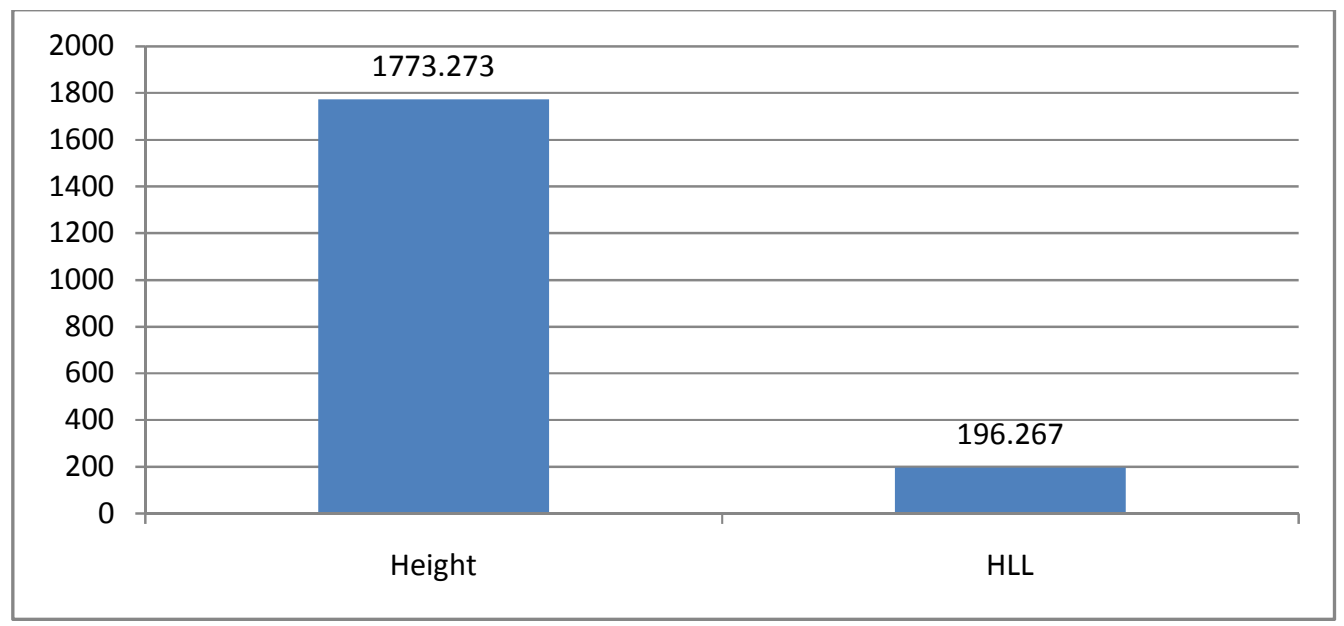

Mean of Height Hand Length Left (HLL) Side Of Adult Males Of Punjabi Origin (Photograph No. 7) 